\title{
PENURUNAN KANDUNGAN BESI (Fe) DAN MANGAN (Mn) PADA AIR SUMUR MENGGUNAKAN MEMBRAN KERAMIK
}

\author{
Merdiana Sari ${ }^{1)}$ dan Setyo Purwoto ${ }^{2)}$ \\ ${ }^{1)}$ Program Studi Teknik Lingkungan, Fakultas Teknik Sipil dan Perencanaan, \\ Universitas PGRI Adi Buana Surabaya \\ Email : merdiana.ms@gmail.com \\ ${ }^{2)}$ Program Studi Teknik Lingkungan, Fakultas Teknik Sipil dan Perencanaan, \\ Universitas PGRI Adi Buana Surabaya \\ Email : setyopurwoto.enviro@gmail.com
}

\begin{abstract}
Increased population growth will put great pressure on the availability of water resources. For areas that have not received clean water services from PAM, people generally use groundwater (wells). Problems arise that is often found that the quality of groundwater used by the community is less qualified. Trying to overcome the problem then do the research decrease of heavy metal content Fe and Mn by using ceramic membrane. The aims of this study were: a) Looking for the most effective ceramic membrane composition of sawdust composition of 3\%, 5\% and 7\% in reducing $\mathrm{Fe}$ and $\mathrm{Mn}$ levels in groundwater; $b$ ) Knowing the efficiency of ceramic membranes; $c$ ) Knowing the effective operation time of the variation of operating time is 1 hour, 2 hours and 3 hours. Ceramic membranes are made with a diameter of $10 \mathrm{~cm}$ and a thickness of $1.5 \mathrm{~cm}$. Variations of the composition of the ceramic membrane to be tested are composition I (300) ie 5000 gram clay, 500gram quartz sand, 150gram sawdust; composition II (500) ie 5000gram clay, 500 gram quartz sand, 250gram sawdust and composition III (700) ie 5000gram clay, 500gram quartz sand, 350gram sawdust. The results showed that the ceramic membrane 700 was able to reduce Fe content in ground water up to $1,981 \mathrm{mg} / \mathrm{L}$ and Mn level up to 0,995 $\mathrm{mg} / \mathrm{L}$.
\end{abstract}

Keywords: Water Supply, Ceramic Membrane, Heavy Metal Fe, Heavy Metal Mn

\section{PENDAHULUAN}

Desa Keboan Singkep Gedangan Sidoarjo memanfaatkan air tanah sebagai sumber air bersih, namun kualitas air tersebut belum memenuhi baku mutu air bersih di parameter Logam Berat Fe dan Mn sesuai yang ditetapkan Permenkes RI No. 416 Tahun 1990. Diperlukan upaya pengolahan untuk menurunkan kadar logam $\mathrm{Fe}$ dan Mn yang terdapat dalam air tanah agar memiliki kualitas yang sesuai dengan baku mutu air bersih. Teknologi membran merupakan salah satu cara atau metode yang sering digunakan karena prosesnya relatif sederhana dan bahanbahannya mudah diperoleh. Sehingga tujuan pada penelitian ini adalah untuk mengetahui :

1. Mencari komposisi membran keramik yang paling efektif dari komposisi serbuk gergaji 3\%, 5\% dan 7\% dalam menurunkan kadar Fe dan Mn pada air tanah.
2. Mengetahui efisiensi membran keramik dalam menurunkan kadar $\mathrm{Fe}$ dan Mn dalam air tanah.

3. Mengetahui waktu operasi yang efektif dari variasi waktu operasi yaitu 1 jam, 2 jam dan 3 jam dalam menurunkan kadar Fe dan Mn pada air tanah.

\section{METODE PENELITIAN}

Metode yang digunakan dalam penelitian ini adalah eksperimen dengan perlakuan membran keramik dibuat dengan tiga variasi yaitu variasi I serbuk gergaji kayu $3 \%$, sedangkan variasi II $5 \%$ dan variasi III serbuk gergaji kayu $7 \%$ dengan perbandingan persen volume, kemudian menganalisa kadar logam $\mathrm{Fe}$ dan $\mathrm{Mn}$ pada air tanah yang telah melewati membran keramik. Populasi dalam penelitian ini adalah air sumur di Desa Keboan Singkep Gedangan Sidoarjo. 
Rancangan kegiatan penelitian digambarkan pada gambar 1 .

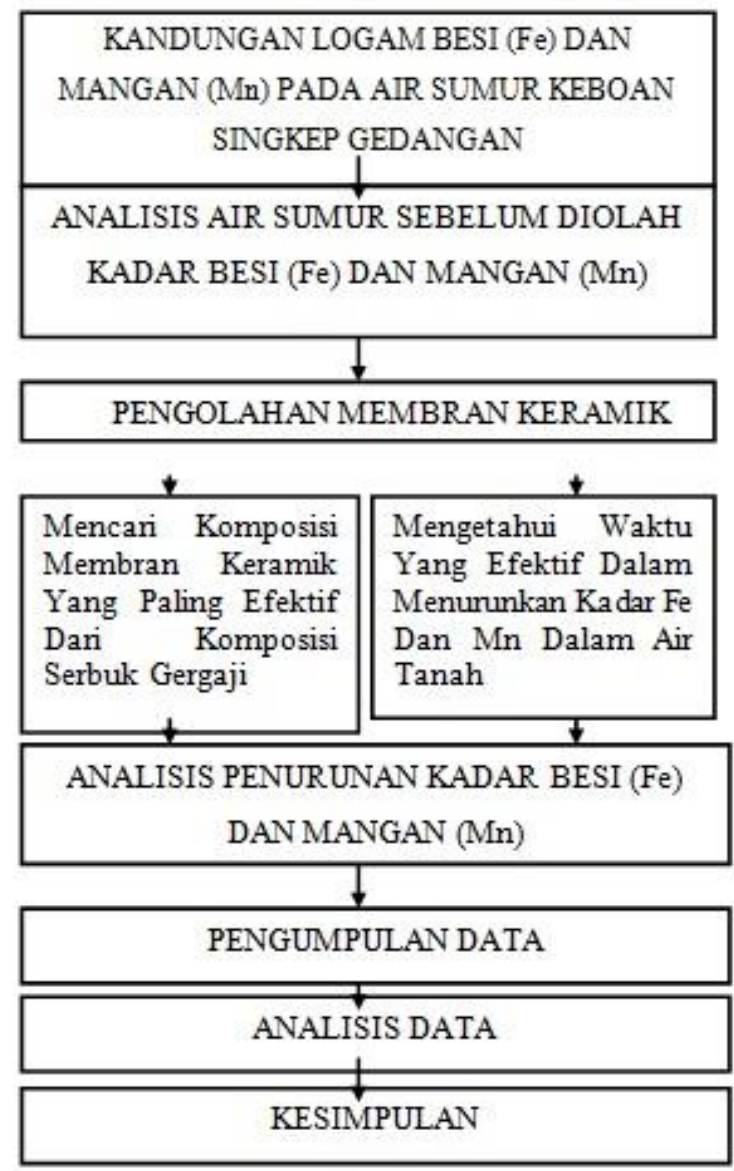

Gambar 1. Rancangan Penelitian

\section{Variabel Terikat}

- Kadar Besi (Fe) dan Mangan (Mn) sebagai parameter air bersih (Metode AAS)

\section{Variabel Bebas}

- Komposisi campuran bahan pembuatan membran keramik : komposisi serbuk gergaji yaitu 150 gram, 250 gram dan 350 gram.

- Waktu operasi yang efektif yaitu 1 jam, 2 jam dan 3 jam dalam menurunkan kadar $\mathrm{Fe}$ dan $\mathrm{Mn}$ dalam air tanah

\section{Variabel Kontrol}

- Suhu pembakaran/sintering membran keramik $600{ }^{\circ} \mathrm{C}$

- Ketebalan membran keramik 1,5 cm

- Keramik dicetak dengan bentuk piringan berdiameter $10 \mathrm{~cm}$

- Ketinggian air selama penelitian $1 \mathrm{~m}$ 


\section{Desain Alat Penelitian}

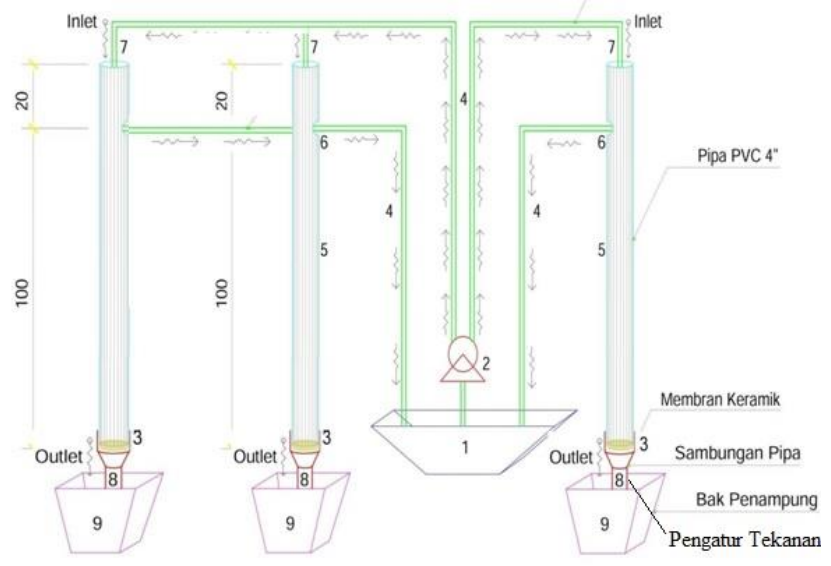

Gambar 2. Desain Alat Penelitian

Keterangan :

1. Bak penampung air baku

2. Pompa

3. Membran keramik, diameter 10 $\mathrm{cm}$, ketebalan $1,5 \mathrm{~cm}$

4. Selang plastik 1,5 "

Alat

1.Botol sampel

2.Furnace

3.Mesin ayakan

4.Gelas ukur

5.Pipa

6.Pompa

7.Bak penampung

8. Peralatan uji parameter kadar $\mathrm{Fe}$ dan Mn

\section{Bahan}

1. Tanah liat

2.Pasir Kwarsa

3. Serbuk Gergaji

4.Sampel air sumur Desa Keboan Singkep Gedangan Sidoarjo

5.Aquades

6.Bahan uji parameter kadar Fe dan $\mathrm{Mn}$
5. Pipa PVC 4", ketinggian $120 \mathrm{~cm}$

6. Pengatur ketinggian air $(100 \mathrm{~cm})$

7. Inlet

8. Outlet dan pengatur tekanan

9. Bak penampung hasil olahan

\section{Pelaksanaan Penelitian}

1. Menyiapkan alat dan bahan yang dibutuhkan

2. Mencuci membran keramik dengan melakukan penyaringan menggunakan aquades terlebih dahulu dengan maksud untuk membilas dan membersihkan kotoran sisa pembakaran.

3. Sampel air dimasukkan ke dalam bak penampung yang sudah dihubungan dengan unit filtrasi menggunakan selang

4. Menghidupkan pompa yang berfungsi untuk menjaga debit aliran sampel

5. Output hasil filtrasi diambil setiap jam selama 3 jam sebagai sampel untuk dianalisis kualitasnya setelah melewati membran.

6.Langkah yang sama dilakukan untuk variasi yang berbeda. 


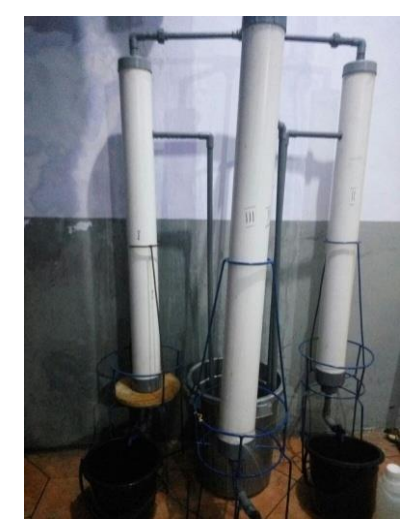

Gambar 3. Rangkaian Alat Penelitian

\section{Pengumpulan Data}

Data yang dikumpulkan adalah volume air yang berhasil tersaring dalam satuan waktu yang diukur dengan gelas ukur dan hasil analisis kualitas air tanah sebelum dan sesudah melewati membran keramik pada parameter kadar Fe dan Mn yang diuji dengan metode AAS. Pengumpulan data sampel hasil pengolahan dilakukan dengan pengambilan sampel air setiap jam selama $3 \mathrm{jam}$. Analisis data dilakukan secara statistika deskriptif dalam bentuk grafik.

\section{HASIL DAN PEMBAHASAN}

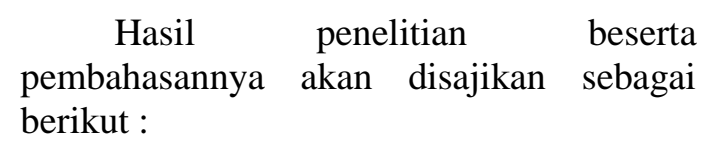

\section{Hasil Pembuatan Membran Keramik}

Komposisi membran keramik divariasikan, variasi yang pertama adalah komposisi tanah liat 5000 gram, pasir kwarsa 500 gram dan serbuk gergaji kayu 150 gram (Kode Membran: 300). Variasi yang kedua adalah tanah liat 5000 gram, pasir kwarsa 500 gram dan serbuk gergaji kayu 250 gram (Kode Membran: 500). Dan variasi yang ketiga adalah tanah liat 5000 gram, pasir kwarsa 500 gram dan serbuk gergaji kayu 350 gram (Kode Membran: 700). Perbandingan komposisi bahan membran keramik ditetapkan berdasarkan volume bahan.

Tabel 1. Komposisi Bahan Pembuatan Membran

\section{Debit Filtrasi}

Data debit filtrasi didapatkan dari pengukuran volume air hasil saring yang

\begin{tabular}{|c|c|c|c|}
\hline \multirow{2}{*}{$\begin{array}{c}\text { Kode } \\
\text { Membran }\end{array}$} & \multicolumn{3}{|c|}{ Komposisi Bahan (gram) } \\
\cline { 2 - 4 } & $\begin{array}{c}\text { Serbuk } \\
\text { Gergaji }\end{array}$ & $\begin{array}{c}\text { Tanah } \\
\text { Liat }\end{array}$ & $\begin{array}{c}\text { Pasir } \\
\text { Kwarsa }\end{array}$ \\
\hline 300 & 150 & 5000 & 500 \\
\hline 500 & 250 & 5000 & 500 \\
\hline 700 & 350 & 5000 & 500 \\
\hline
\end{tabular}

dikonversikan menjadi satuan liter per hari. Grafik perbandingan filtrasi masing-masing membran keramik adalah sebagai berikut : 


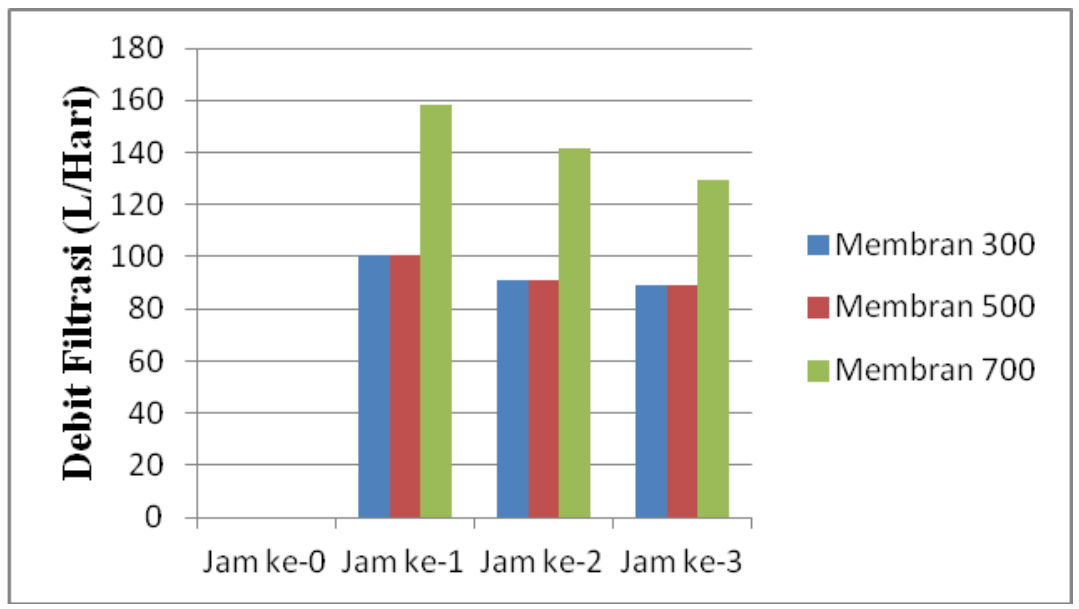

Gambar 4. Grafik Debit Filtrasi

Membran keramik 300 pada jam ke-1 mampu menyaring air baku dengan debit 100,8 L/hari, kemudian terus menurun hingga di jam ke-3 mampu menyaring air baku dengan debit $88,8 \mathrm{~L} /$ hari. Sedangkan Membran keramik 500 mampu menyaring air dengan debit lebih besar dari membran keramik 300, pada jam ke-1 mampu menyaring air baku dengan debit 158,4 L/hari, kemudian terus menurun hingga di jam ke-3 mampu menyaring air baku dengan debit 129,6 L/hari. Sedangkan Membran keramik 700 mampu menyaring air dengan debit lebih besar dari membran keramik 300 dan membran keramik 500, pada jam ke-1 mampu menyaring air baku dengan debit 177,6 L/hari, kemudian terus menurun hingga di jam ke-3 mampu menyaring air baku dengan debit 148,8 L/hari.

Penurunan yang terjadi disebabkan adanya endapan-endapan berupa logam dan mikroorganisme yang menghambat laju filtrasi air sehingga pada waktu tertentu terjadi proses kejenuhan. Ketika debit filtrasi dirasa semakin tidak memenuhi kebutuhan maka membran keramik dapat diaktivasi lagi (Febrina dan Ayuna, 2014).

\section{Logam Berat Fe dan Mn}

Analisis data hasil uji laboratorium parameter logam berat Fe dan Mn bertujuan untuk mengetahui pola kualitas air hasil olahan berdasarkan variasi komposisi membran keramik dan interval waktu pengolahan yang menunjukan lama usia pakai membran keramik. Kadar Logam Fe dan Mn disajikan berupa kadar logam Fe dan Mn pada air tanah sesudah melewati membran keramik, kadar logam Fe dan Mn yang berhasil disisihkan oleh membran keramik, serta besar efisiensi membran keramik dalam menurunkan kadar logam Fe dan Mn. Kadar Logam Fe dan Mn hasil uji laboratorium terhadap air tanah yang belum melewati membran keramik disajikan dalam tabel 2.

Tabel 2. Kadar Logam Fe dan Mn Sebelum Melewati Membran Keramik

Hasil analisis data logam berat $\mathrm{Fe}$

\begin{tabular}{c|c}
\hline $\begin{array}{c}\text { Kadar Logam } \\
\mathrm{Fe}(\mathrm{Mg} / \mathrm{L})\end{array}$ & $\begin{array}{c}\text { Kadar Logam } \\
\mathrm{Mn}(\mathrm{Mg} / \mathrm{L})\end{array}$ \\
\hline 2,016 & 1,033 \\
\hline
\end{tabular}

dan Mn setelah melewati membran keramik dapat dilihat pada gambar 5 dan 8 . 


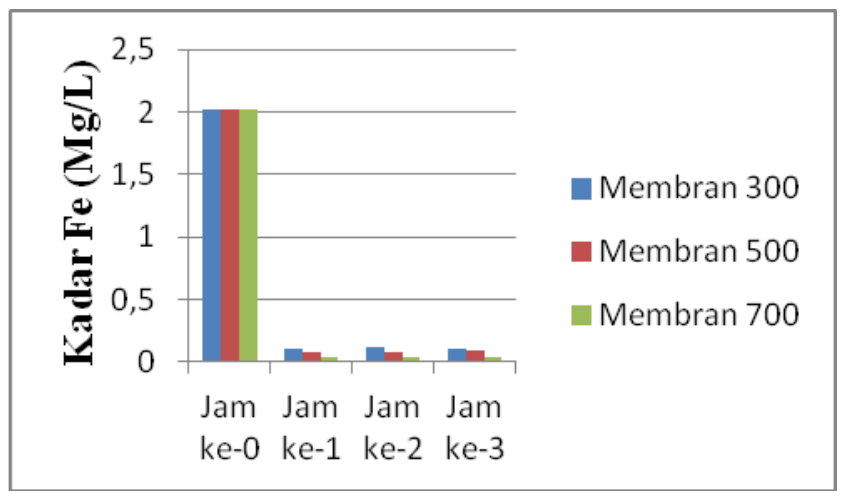

Gambar 5. Grafik Hasil Uji Logam Berat Fe Setelah Melewati Membran Keramik

Membran keramik 700 berada lebih rendah dari grafik merah yang menunjukan kadar logam berat Fe dari air hasil saringan membran keramik 500 dan grafik biru air hasil saringan membran keramik 300. Hal tersebut berarti air hasil saring menggunakan membran 700 memiliki kualitas lebih baik dari pada air hasil saring menggunakan membran 500 dan 300 di parameter logam berat Fe.

Interval waktu pengolahan yang menunjukkan lama usia pakai membran keramik tidak mempengaruhi kualitas air hasil saring secara signifikan. Dilihat dari Gambar 4.2 grafik hasil uji logam berat $\mathrm{Fe}$ berdasarkan interval waktu pengolahan mengalami kenaikan maupun penurunan. Kadar logam berat $\mathrm{Fe}$ air hasil saring membran 700 terkecil didapatkan pada pengambilan sampel di jam ke-3 yaitu sebesar $0,035 \mathrm{mg} / \mathrm{L}$, sedangkan kadar terbesar didapatkan pada pengambilan sampel di jam ke-1 sebesar $0,04 \mathrm{mg} / \mathrm{L}$. Sedangkan kadar logam berat $\mathrm{Fe}$ air hasil saring membran 500 terkecil didapatkan pada pengambilan sampel di jam ke-2 sebesar $\quad 0,081 \mathrm{mg} / \mathrm{L}$, sedangkan kadar terbesar didapatkan pada pengambilan sampel di jam ke-3 sebesar $0,087 \mathrm{mg} / \mathrm{L}$. Sedangkan kadar logam berat Fe air hasil saring membran 300 terkecil didapatkan pada pengambilan sampel di jam ke-3 sebesar $\quad 0,107 \mathrm{mg} / \mathrm{L}$, sedangkan kadar terbesar didapatkan pada pengambilan sampel di jam ke-2 sebesar 0,113mg/L.

Berdasarkan analisis data hasil uji logam berat $\mathrm{Fe}$, kadar logam berat Fe pada air hasil saring menggunakan membran keramik 300, 500 dan 700 pada lama usia pakai hingga 3 jam telah memenuhi baku mutu air bersih menurut Permenkes RI Nomor 416 Tahun 1990 yaitu sebesar 1,0 $\mathrm{mg} / \mathrm{L}$.

Dibandingkan dengan hasil penelitian yang lain, dalam hal removal zat Besi $(\mathrm{Fe})$, dengan menggunakan treatment yang berbeda didapatkan penurunan Besi (Fe) sebesar 0,18 ppm (dari bahan baku 0,42 menjadi 0,24 ppm) menggunakan treatment Sediment Poly Propylene, Carbon Block, Manganese Zeolite, Ion Exchange, dan membran Reverse Osmosis (RO) (Purwoto, S. et al., (2014).

Sedangkan hasil kajian (Nurhayati, I., \& Purwoto, S. 2014a) penyisihan zat Besi (Fe) sebesar 0,22 ppm dari sampel 0,52 menjadi 0,30 ppm menggunakan perlakuan kombinasi koagulan aid, ion exchange, dan membran Reverse Osmosis (RO).Analisis data kadar logam berat $\mathrm{Fe}$ yang berhasil disisihkan oleh masing-masing jenis membran dapat dilihat pada Gambar 6 . 


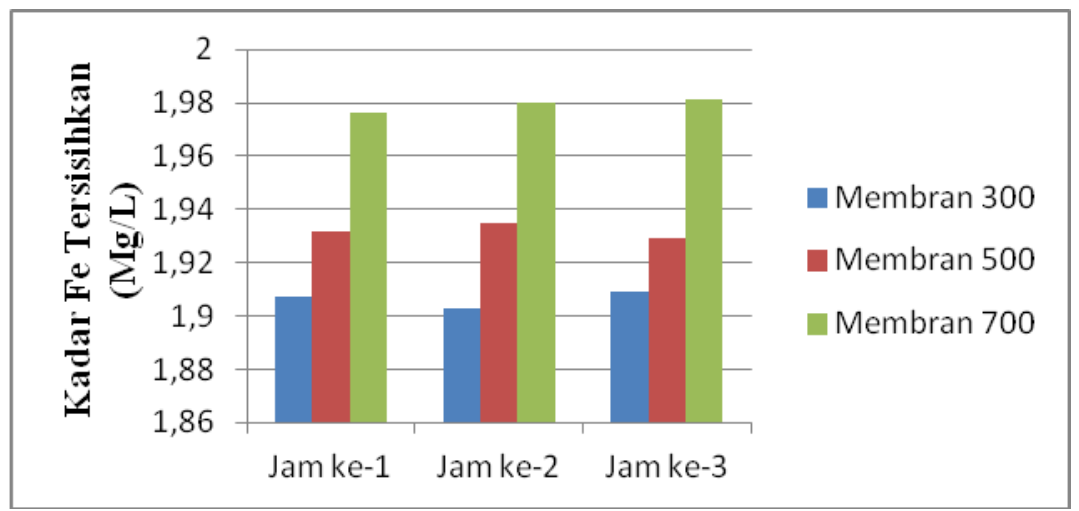

Gambar 6. Grafik Kadar Logam Berat Fe yang Tersisihkan

Hasil analisis data efisiensi hasil saring masing-masing membran penurunan Kadar Logam Berat Fe pada air keramik disajikan pada gambar 7.

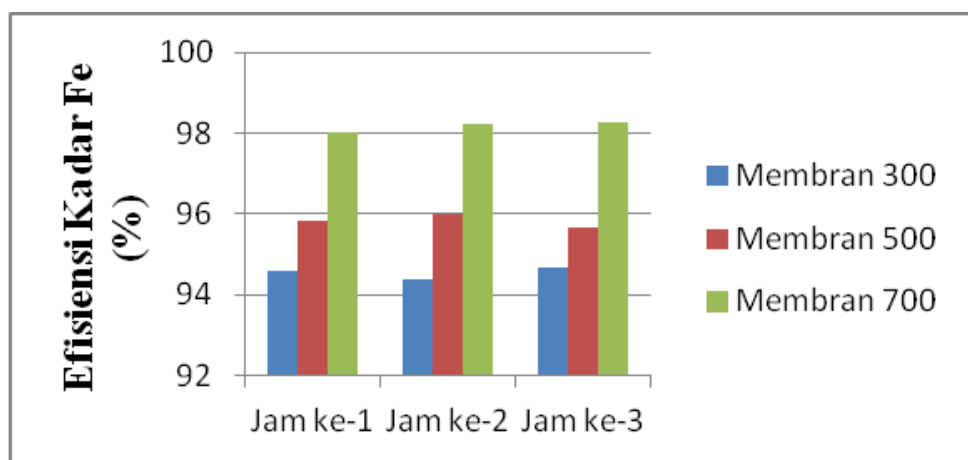

Gambar 7. Grafik Efisiensi Penurunan Kadar Logam Berat Fe

Efisiensi penurunan kadar logam berat $\mathrm{Fe}$ membran 700 terkecil didapatkan pada pengambilan sampel di jam ke-1 sebesar $98,02 \%$, sedangkan efisiensi tertinggi didapatkan pada pengambilan sampel di jam ke-3 sebesar 98,26\%. Untuk efisiensi penurunan kadar logam berat $\mathrm{Fe}$ membran 500 terkecil didapatkan pada pengambilan sampel di jam ke-3 sebesar 95,68\%, sedangkan efisiensi tertinggi didapatkan pada pengambilan sampel di jam ke-2 sebesar 95,68\%. Sedangkan efisiensi penurunan kadar logam berat $\mathrm{Fe}$ membran 300 terkecil didapatkan pada pengambilan sampel di jam ke-2 sebesar 94,39\%, sedangkan efisiensi tertinggi didapatkan pada pengambilan sampel di jam ke-3 sebesar 94,69\%. Untuk menghilangkan kandungan Besi $(\mathrm{Fe})$ dan Mangan (Mn) dapat pula menggunakan Manganese Greensand (MGS), dimana lapisan atas berminyak di dalam air sebagai katalis dan pada waktu yang bersamaan, besi dan mangan yang ada dalam air teroksidasi menjadi bentuk ferri-oksida dan mangandioksida yang tak larut dalam air. (Purwoto Putri et al, 2016)

Nurhayati, I., \& Purwoto, S. (2014b) dalam pengolahan air payau berbasis kimiawi melalui tekno membran reverse osmosis (RO) terpadukan dengan koagulan dan penukar ion diperoleh removal parameter Besi ( $\mathrm{Fe})$ sebesar $0.13 \mathrm{mg} / \mathrm{L} \mathrm{Fe}$ (dari 0,21 menjadi 0,08). 


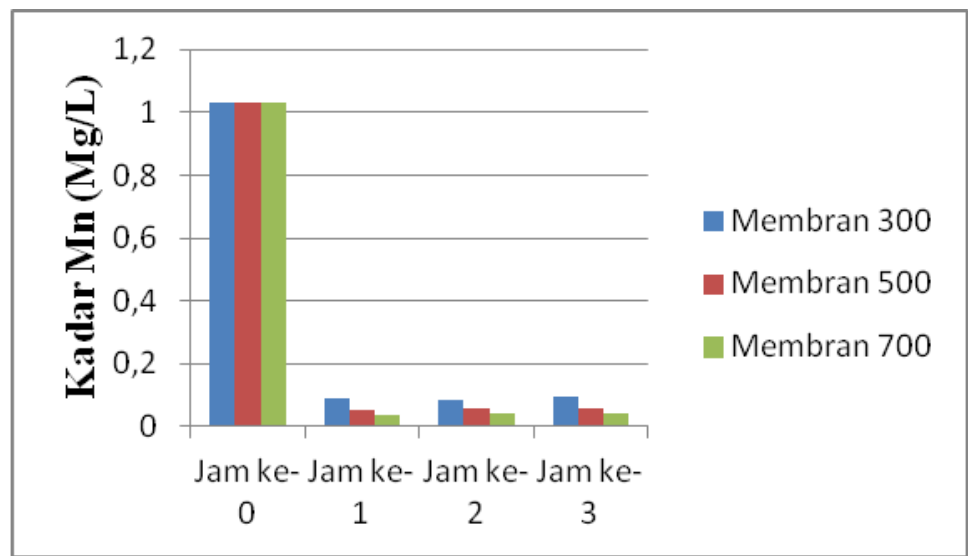

Gambar 8. Grafik Hasil Uji Logam Berat Mn Setelah Melewati Membran Keramik

Membran keramik 700 berada lebih rendah dari grafik merah yang menunjukan kadar logam berat $\mathrm{Mn}$ dari air hasil saringan membran keramik 500 dan dari grafik biru yang menunjukan kadar logam berat Mn dari air hasil saringan membran keramik 300. Hal tersebut berarti air hasil saring menggunakan membran 700 memiliki kualitas lebih baik dari pada air hasil saring menggunakan membran 500 dan membran 300 di parameter logam berat Mn. Untuk membran 300 dan 500 diperoleh data yang berlawanan, dikarenakan kemungkinan hasil analisa laboratorium yang tidak akurat, untuk itu penelitian selanjutnya sebaiknya dilakukan replikasi pengulangan pengambilan data.

Interval waktu pengolahan yang menunjukkan lama usia pakai membran keramik tidak mempengaruhi kualitas air hasil saring secara signifikan. Dilihat dari Gambar 4.2 grafik berdasarkan interval waktu pengolahan mengalami kenaikan maupun penurunan. Kadar logam berat Mn air hasil saring membran 700 terkecil didapatkan pada pengambilan sampel di jam ke-1 sebesar 0,038mg/L, sedangkan kadar terbesar didapatkan pada pengambilan sampel di jam ke-3 sebesar $0,043 \mathrm{mg} / \mathrm{L}$. Sedangkan kadar logam berat Mn air hasil saring membran 500 terkecil didapatkan pada pengambilan sampel di jam ke-1 sebesar $0,055 \mathrm{mg} / \mathrm{L}$, sedangkan kadar terbesar didapatkan pada pengambilan sampel di jam ke-2 sebesar $0,059 \mathrm{mg} / \mathrm{L}$. Sedangkan kadar logam berat Mn air hasil saring membran 300 terkecil didapatkan pada pengambilan sampel di jam ke-2 sebesar 0,086mg/L, sedangkan kadar terbesar didapatkan pada pengambilan sampel di jam ke-3 sebesar 0,093 mg/L.

Berdasarkan analisis data hasil uji logam berat $\mathrm{Mn}$, kadar logam berat Mn pada air hasil saring menggunakan membran keramik 300, 500 dan 700 pada lama usia pakai hingga 3 jam telah memenuhi baku mutu air bersih menurut Permenkes RI Nomor 416 Tahun 1990 yaitu sebesar $0,50 \mathrm{mg} / \mathrm{L}$.

Analisis data kadar logam berat Mn yang berhasil disisihkan oleh masing-masing jenis membran dapat dilihat pada Gambar 9. 


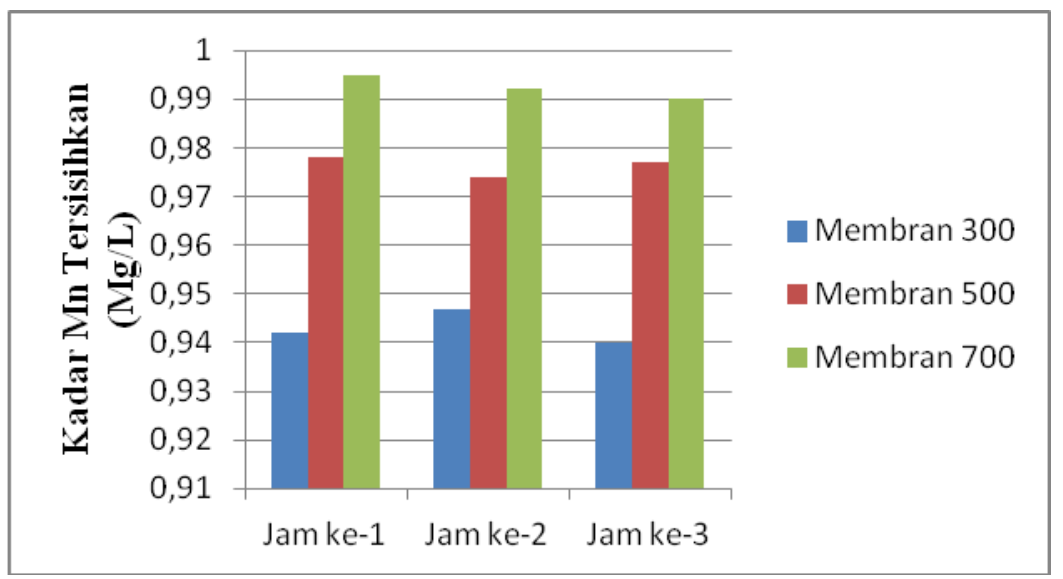

Gambar 9. Grafik Kadar Logam Berat Mn yang Tersisihkan

Hasil analisis data efisiensi hasil saring masing-masing membran penurunan Kadar Logam Berat Mn pada air keramik disajikan pada gambar 10.

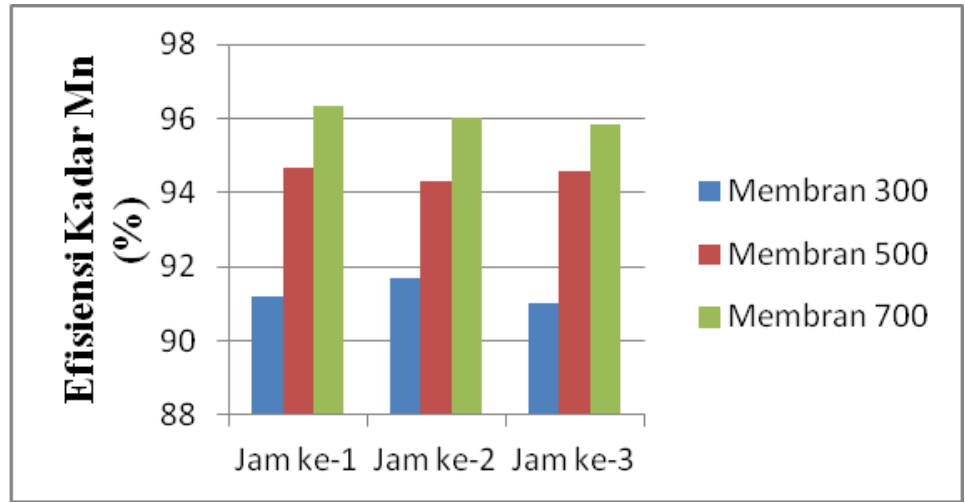

Gambar 10. Grafik Efisiensi Penurunan Kadar Logam Berat Mn

Efisiensi penurunan kadar logam berat $\mathrm{Mn}$ membran 700 terkecil didapatkan pada pengambilan sampel di jam ke-3 sebesar 95,84\%, sedangkan efisiensi tertinggi didapatkan pada pengambilan sampel di jam ke-1 sebesar 96,32\%. Untuk efisiensi penurunan kadar logam berat $\mathrm{Mn}$ membran 500 terkecil didapatkan pada pengambilan sampel di jam ke-2 sebesar $94,29 \%$, sedangkan efisiensi tertinggi didapatkan pada pengambilan sampel di jam ke-1 sebesar 94,67\%. Sedangkan efisiensi penurunan kadar logam berat $\mathrm{Mn}$ membran 300 terkecil didapatkan pada pengambilan sampel di jam ke-3 sebesar $90,99 \%$, sedangkan efisiensi tertinggi

\section{KESIMPULAN}

Dari hasil penelitian ini dapat disimpulkan bahwa :

1. Membran keramik dengan komposisi serbuk gergaji 350 gram, tanah liat 5000 gram dan pasir kwarsa 500 gram didapatkan pada pengambilan sampel di jam ke-2 sebesar 91,67\%.

Mengacu pada temuan (Rachmah, N. \& Purwoto, S. 2014) filter zeolit alam, Manganese Green Sand dan Zeolit teraktivasi dengan pemanasan, dimana reaktor yang digunakan tinggi $100 \mathrm{~cm}$, kedalaman media $60 \mathrm{~cm}$, diameter zeolit alam mess 16 - mess 7, diameter manganese green sand mess 30 - mess 12 dan diameter zeolit teraktivasi dengan pemanasan mess 16 - mess 7 didapatkan penurunan kandungan $\mathrm{Mn}$ rata -rata sebesar $0,099 \mathrm{mg} / \mathrm{lt}$ dari $2,53 \mathrm{mg} / \mathrm{lt}$. Terdapat perbedaan kemampuan removal Mn dengan penelitian tersebut karena adanya perbedaan perlakuan.

paling efektif dalam menurunkan Kadar Fe dan Mn pada air tanah.

2. Efisiensi yang paling baik adalah membran keramik dengan komposisi serbuk gergaji 350 gram, tanah liat 5000 gram dan pasir kwarsa 500 gram 
mampu menurunkan kadar logam berat Fe pada air tanah hingga 1,981 mg/L yaitu dari air baku yang memiliki kadar logam berat $\mathrm{Fe}$ sebesar 2,016 $\mathrm{mg} / \mathrm{L}$ menjadi $0,035 \mathrm{mg} / \mathrm{L}$ pada saat pengambilan sampel di jam ke-3 serta mampu menurunkan kadar logam berat Mn pada air tanah hingga 0,995 mg/L yaitu dari air baku yang memiliki

\section{REFERENSI}

Allo, D.T.P. ,Zakir, M. , dan Nafie, N.L. (2014). "Pemanfaatan Serbuk Kayu Meranti Merah (Shoreaparyifolia Dyer) sebagai Biosorben Ion Logam $\mathrm{Cu}(\mathrm{II})$ " Indonesia Chimica Acta. Vol 4 (2) : 1-14.

Asmadi., Khayan., Kasjono, Heru Subaris, (2011). "Teknologi Pengolahan Air Minum" Yogyakarta, Gosyen Publishing.

Febrina, Laila dan Ayuna, Astrid. (2014). "Studi Penurunan Kadar Besi (Fe) Dan Mangan (Mn) Dalam Air Tanah Menggunakan Saringan Keramik". Jurnal Teknologi. Jurusan Teknik Lingkungan, Universitas Sahid, Jakarta.

Nasir, S dan Teguh Budi SA. (2011). "Pengolahan Air Limbah Hasil Proses Laundry Menggunakan Filter Keramik Berbahan Tanah Liat Alam dan Zeolit" Laporan Hibah Kompetitif 2011, Universitas Sriwijaya, Indralaya

Notodarmojo, Supriharton dan Anne Deniva. (2004). "Penurunan zat Organik dan Kekeruhan menggunakan Teknologi Membran Ultrafiltrasi dengan Sistem aliran Deat-End".

Nurhayati, I., \& Purwoto, S. (2014), "The Combination of Coagulant Aid, Ion Exchanger, and Reverse Osmosis (RO ) on Brackish Water Treatment" Journal of Natural Sciences Research 4 (24), 26-30.

Nurhayati, I. \& Purwoto, S. (2014), "Pengolahan Air Payau Berbasis Kimiawi Melalui Tekno Membran kadar logam berat Mn sebesar 1,033 $\mathrm{mg} / \mathrm{L}$ menjadi $0,038 \mathrm{mg} / \mathrm{L}$ pada saat pengambilan sampel di jam ke-1.

3. Waktu operasi yang efektif dari variasi waktu operasi antara 1 jam, 2 jam dan 3 jam dalam menurunkan kadar $\mathrm{Fe}$ dan Mn pada air tanah adalah 3 jam

Reverse Osmosis (RO) Terpadukan Dengan Koagulan Dan Penukar Ion" Seminar Nasional Kimia-FMIPA Unesa ISBN:978-602-0951-00-3, B 169-177

http://fmipa.unesa.ac.id/kimia/prosed ing-2014/

Peraturan Menteri Kesehatan Nomor 416/MENKES/PER/IX/1990 tentang Syarat-syarat dan Pengawasan Kualitas Air.

Purwoto, S. (2009), " Desalinasi Air Payau Secara Ion Exchange dengan Treatmen Resin

Sintetis" Waktu 7 (01), 52-59.

Purwoto, S., Sopandi, T., Kusuma, P.S.W., \& Nurcahyanie, Y.D. (2014), "Removal Parameters of Clean Water using Treatment; Sediment Poly Propylene, Carbon Block, Manganese Zeolite, Ion Exchange, and Reverse Osmosis (RO)." Journal of Environment and Earth Science 4 (23), $72-77$.

Purwoto, S., Purwanto, T., \& Hakim, L. (2016). "Penjernihan Air Sungai Dengan Perlakuan Koagulasi, Filtrasi, Absorbsi dan Pertukaran Ion." WAKTU, 13(2), 45-53.

Rachmah, N. \& Purwoto, S. (2014), "Efektifitas Penurunan Mn dan Total Coliform Pada Air Sumur Gali Berbasis Zeolit" Jurnal WAKTU 12 (01), 1-7.

Sawyer, Clain N. (1994) . Chemistry for Enviromental Engineering . New York: McGraw-Hill. 